\title{
FITOSSANIDADE
}

\section{INTERAÇÃO ENTRE COLLETOTRICHUM GLOEOSPORIOIDES E ECÓTIPOS DE PINHA $\left(^{1}\right)$}

\author{
ANA MARIA QUEIJEIRO LÓPEZ $\left({ }^{2 *}\right)$ DANIELLE DOS SANTOS TAVARES PEREIRA $\left({ }^{2}\right)$
}

\begin{abstract}
RESUMO
A produção brasileira de pinha (Annona squamosa L.) predomina no Nordeste, sendo afetada pela antracnose causada por Colletotrichum gloeosporioides. Este estudo avaliou: 1) as taxas de crescimento micelial e conidiação, dimensões de conídios e produção de amilase, xilanase, pectinases e protease por isolado desse fungo de lesões de abacate (Persea americana Mill), em diferentes meios; 2) as porcentagens de germinação e formação de apressórios do mesmo sobre folhas jovens de pinha; 3) as alterações in vivo nos teores de proteínas, fenóis e carboidratos solúveis totais, antes e após a inoculação. Folhas jovens de plântulas de dois ecótipos de pinha (PI e CT) foram destacadas, submetidas à inoculação e incubadas ou para sua extração (0 e 36 horas após), ou para seu clareamento (0,12, 18, 24, 30, 36, 42 e 46 horas após), coloração e análise ao microscópio. Particionou-se cada extrato contra hexano, e a fração polar foi concentrada e resolubilizada para determinação dos parâmetros bioquímicos mencionados. Verificou-se maior esporulação do isolado fúngico em meio Mathur, e este produziu todas as enzimas ensaiadas in vitro. In vivo, este foi mais agressivo ao ecótipo PI, mas verificou-se ca. de $80 \%$ de germinação e $50 \%$ de formação de apressórios após 24 e 30 horas de incubação respectivamente sobre os ecótipos PI e CT. Os teores de proteínas, glicídeos redutores e fenóis totais dos extratos de CT foram mais elevados 36 horas após a inoculação, enquanto apenas uma ligeira elevação no conteúdo de fenóis foi constatada nos extratos de PI.
\end{abstract}

Palavras-chave: Annona; Colletotrichum; pinha; antracnose; resistência bioquímica.

(1) Recebido para publicação em 3 de junho de 2008 e aceito em 20 de outubro de 2009.

$\left({ }^{2}\right)$ Universidade Federal Alagoas, Instituto de Química e Biotecnologia, Tabuleiro do Martins, 57972-070 Maceió (AL). E-mail:amql@qui.ufal.br $\left(^{*}\right)$ Autora correspondente. 


\title{
ABSTRACT \\ INTERACTION BETWEEN COLLETOTRICHUM GLOEOSPORIOIDES AND ECOTYPES OF SUGAR APPLE
}

\begin{abstract}
The Brazilian production of sugar-apple (Annona squamosa L.) predominates in the Northeast, being affected by anthracnose caused by Colletotrichum gloeosporioides. This study evaluated:1) the rates of micelial growth, conidiation, size of conidia and production of amylase, xylanase, protease and pectinases by the fungus isolated from lesions of avocado (Persea americana Mill), in different media; 2 ) the percentage of its germination and formation of appressoria on the young leaves of sugar apple; 3) the in vivo changes in levels of total proteins, phenols and soluble carbohydrates, before and after inoculation. Young leaves of two different ecotypes of sugar apple (PI and CT) were detached, inoculated and incubated either for their extraction (after 0 and 36 hours), or for its clearing (after 12, 18, 24, 30, 36,42 and 46 hours), staining and analysis under the microscope. Each extract was partitioned against hexane, and the polar fraction was concentrated and re-solubilized for determination of biochemical parameters above mentioned. It was observed a higher sporulation of the fungal isolate in Mathur's medium, and it has produced all the enzymes tested in vitro. In vivo, this was more aggressive on the ecotype PI. There was ca. $80 \%$ germination and $50 \%$ of appressoria formation of the same after 24 and 30 hours of incubation on the ecotypes PI and CT respectively. The levels of total proteins, phenols and reducing glycids in extracts of CT were higher at 36 hours after inoculation, while only a slight increase in phenolic content was detected in extracts of PI.
\end{abstract}

Key words: Annona; Colletotrichum; sugar apple; anthracnose; biochemical resistance.

\section{INTRODUÇÃO}

A pinha, ata ou fruta-do-conde (Annona squamosa L.) é uma anonácea de importância econômica em diversos países. No Brasil, sua produção ocorre em áreas quentes com chuvas esparsas, desde o Norte até o Sudeste. Os maiores produtores são os Estados de Alagoas, da Bahia e de São Paulo, com área cultivada de ca. de 10.500 ha, dos quais 7.100 ha estão situados na Bahia, cuja produção anual dessa fruta é de aproximadamente 80.000 ton (Mattos, 2007; Pelinson, 2005). A pinha é geralmente consumida in natura, podendo ainda ser processada ou não com leite. A infusão de suas folhas possui propriedades laxativa e anti-hipertireoidiana, e tem sido documentado que suas sementes agem como inseticidas e antimicrobianos (BRITO et al., 2008).

A antracnose ou manha foliar é uma doença que atinge a parte aérea das plantas, com sintomas e sinais nas folhas, flores e frutos. É causada por fungos do gênero Colletotrichum, sendo C. gloeosporioides (Penz) Sacc (teliomorfo Glomerella cingulata) a espécie mais frequente e agressiva a hospedeiras distintas taxonomicamente (LóPez, 2001; PONTE, 1996). Os sintomas provocados por C. gloeosporioides em diferentes tecidos de pinha têm basicamente a mesma fenologia que em outras plantas, como lesões irregulares no limbo ou nas nervuras, as quais são inicialmente pardo-escuras e, depois, esbranquiçadas no centro e cercadas de pontuações pretas salientes. No estágio final, o tecido doente e necrosado atua como fonte de inóculo. O mesmo ocorre com as flores. Os frutos são particularmente suscetíveis quando maduros, enfatizando a importância de um controle eficaz dessa doença sem danos à saúde do consumidor (LóPEZ, 2005).

A razão principal da incapacidade de algumas espécies de Colletotrichum em infectarem gêneros e famílias de não-hospedeiros deve-se, provavelmente, à sua deficiência para enfrentar mecanismos físicos não relacionados àqueles da chamada "resposta de hipersensibilidade" (HR). Muitos deles operam nãoespecificamente durante a infecção por raças incompatíveis ou compatíveis a cultivares do hospedeiro. Em tais casos, uma pequena proporção de células epidérmicas abaixo dos apressórios torna-se infectada pelo fungo. Essas defesas agem de forma coordenada ou isolada e temporal, tanto em nível celular como molecular, e podem auxiliar as plantas a resistirem contra o patógeno, conforme diferentes eventos cuja ativação é geneticamente controlada, ainda que aparentemente reprimida (DEAN e KUC', 1987; Esquerré-Tugayé et al., 1992; LATUNDE-DADA e Lucas, 2001, 2007; MAZau e Esquerré-Tugayé, 1986; Mould et al., 1991a, 1991b; SOMMER-KNUDSEN et al., 1998).

Entretanto, em interações como aquelas entre C. gloeosporioides f.sp. malvae e malváceas, os determinantes de compatibilidade ou incompatibilidade não operam durante a fase de prépenetração, mas sim 24 horas após o sucesso da invasão por alguns poucos propágulos dos muitos que se depositaram sobre a epiderme (Morin et al., 1996). Esta HR ocorre em função da síntese e/ou acúmulo de compostos, tais como peroxidases (EC 1.11.1.7), ácido salicílico, fitoalexinas e outras substâncias pré- 
formadas e com massa molecular relativamente baixa (DANN et al., 1996; HARRISON et al., 1995; XUE et al., 1998). Acúmulo de glicoproteínas ricas em hidroxi-prolina e inibidores de proteinases, bem como o aumento da resistência foram também observados em folhas suscetíveis de alfafa, feijão e melão previamente inoculadas com baixas concentrações das respectivas espécies compatíveis de Colletotrichum (EsQuerRéTUGAYÉ et al., 1992). Desde então, resistência local e sistêmica tem sido ativada contra uma série de espécies de Colletotrichum, através de agentes persistentes de baixo nível de estresse, biótico ou abiótico, tais como sais de cobre ou fosfato, sílica, ácido salicílico, ácido 2,6-dicloro-isonicotínico e o S-metil-acilbenzolar (benzo $[1,2,3]$ tiadiazole-7- ácido carbotioico-S-metil ester) (ECHEVERri et al., 1997; FAWE et al., 1998; LATUNDE-DADA e LuCAS, 2001; LOPEZ e LuCAS, 2002).

Considerando-se a importância da produção de pinha para as regiões produtoras e a necessidade de desenvolver e otimizar o controle da antracnose nessa cultura, este trabalho visou caracterizar morfoculturalmente e bioquimicamente um isolado de C. gloeosporioides proveniente de outra hospedeira, bem como estudar as respostas iniciais dos tecidos foliares de dois diferentes ecótipos de pinha, diante desse fungo, fornecendo subsídios para o entendimento do processo de infecção.

\section{MATERIAL E MÉTODOS}

\section{Material biológico}

Sementes de pinha provenientes de diferentes lavouras de cultivo do Estado de Alagoas foram coletadas para a produção das plântulas utilizadas nos experimentos. Estes ecótipos foram denominados "Palmeira dos Índios" (PI) e "Centenário" (CT). Tais materiais foram semeados em viveiros de solo composto, nas condições estabelecidas pelo manual de instruções técnicas para produção de ateiras, de ARAújo FilHo et al. (1998) e utilizados quando atingiram uma altura de cerca de $50 \mathrm{~cm}$, fornecendo para os experimentos sempre as duas primeiras folhas jovens a partir do ápice.

Com relação ao patógeno, utilizou-se o isolado de $C$. gloeosporioides obtido de lesões de antracnose em frutos de abacate comercialmente adquiridos. Para tanto, o tecido circundante e subjacente a tais lesões foi desinfetado seqüencialmente com soluções aquosas de álcool $(70 \%)$ e hipoclorito de sódio (1\%), e incubados em placa de Petri com meio de cultura Batata-Dextrose-Ágar (BDA), por 7 dias $\left(28 \pm 2{ }^{\circ} \mathrm{C}\right.$, escuro). A partir dessas culturas iniciais, realizou-se a transferência de discos de ágar-micélio (cerca de 5 mm de diâmetro) do fungo para novas placas de Petri e tubos de ensaio contendo meio BDA, para manutenção sob refrigeração $\left(6 \pm 2{ }^{\circ} \mathrm{C}\right)$ ou incubadora $\left(28 \pm 2{ }^{\circ} \mathrm{C}\right.$, escuro). Um desses cultivos foi utilizado nos ensaios de seleção de meios para melhor crescimento micelial e esporulação.

\section{Crescimento e esporulação de $C$. gloeosporioides in vitro}

A partir dos cultivos iniciais em BDA, provenientes do isolamento do patógeno de lesões de abacate, discos de ágar-micélio (cerca de $5 \mathrm{~mm}$ de diâmetro) do patógeno foram transferidos para placas de Petri contendo os meios de BDA, Agar-aveia (LópeZ, 1991; López, 1999) e Mathur (Mathur et al., 1950; Tu, 1985), buscando estabelecer uma situação ideal para os parâmetros de esporulação e crescimento in vitro. Avaliaram-se as taxas de crescimento micelial (diâmetro em $\mathrm{mm}$ ) e de esporulação nos diferentes meios, durante os sete dias de incubação $\left(28 \pm 2{ }^{\circ} \mathrm{C}\right.$, escuro). O delineamento experimental foi inteiramente casualizado com cinco repetições, sendo três réplicas para cada meio testado.

As dimensões comprimento e largura dos conídios do fungo estudado foram mensuradas após sete dias de incubação em meio de Mathur, com o auxílio de ocular micrométrica Coleman, sob microscopia óptica $(640 \mathrm{X})$. Para tanto, utilizaram-se as suspensões provenientes da lavagem de colônias com $10 \mathrm{~mL}$ de solução aquosa $(0,1 \%)$ de Tween 20 . Foram mensurados, pelo menos, 100 conídios por suspensão aquosa de cada cultivo em placa, de cada repetição. Depois de selecionado o meio ótimo para a esporulação, o fungo passou a ser cultivado e incubado nas condições já descritas. Os cultivos mantidos em incubadora foram transferidos a cada sete dias (e submetidos sempre às mesmas condições de $28 \pm 2{ }^{\circ} \mathrm{C}$ e escuro), para serem utilizados nos diferentes ensaios.

\section{Produção de exoenzimas por C. gloeosporioides in vitro}

As atividades amilolítica (EC 3.2.1), proteolítica (EC 3.4.21), pectinolítica [pectato-liase (EC 4.2.2.2) e poligalacturonase (EC 3.2.1.15)] de enzimas secretadas pelo isolado do fungo estudado foram mensuradas in vitro conforme metodologia modificada de Hankin e Anagostakis (1975). Também se avaliou a atividade xilanolítica (EC 3.2.1.8), através de metodologia descrita por FERREIRA et al. (2002). Assim, misturou-se $15 \mathrm{~g}$ de papel ofício branco picotado com $400 \mathrm{~mL}$ de água destilada, e homogeneizou-se esse material com o auxílio de um liquidificador, até obterse um líquido pastoso. A esse material, acrescentou-se 5,0 g de ágar e ajustou-se o $\mathrm{pH}$ para 6,0. 
Após autoclavagem, distribuição em placas de Petri e inoculação dos meios sólidos com discos de ágar-micélio do patógeno $(\theta \cong 5,0 \mathrm{~mm})$, as colônias deste foram medidas perpendicularmente com o auxílio de paquímetro, depois de três dias de incubação ( $28 \pm 2{ }^{\circ} \mathrm{C}$, escuro). A atividade das exoenzimas foi constatada pela presença de um halo claro nítido característico ao redor das colônias, após depositar-se sobre elas 5,0 mL de revelador específico para intensificar tais áreas de cada atividade enzimática (lugol para amilase e xilanase; vermelho de fenol $(0,2 \%)$ para protease; solução saturada de hexadeciltrimetilamônio e vermelho de metila $(2,0 \%)$ para pectinases).

\section{Reações de folhas de dois ecótipos de pinha a $C$. gloeosporioides}

Nesse ensaio experimental foram verificadas respostas bioquímicas de 48 folhas jovens $\left(1 .^{\mathrm{a}}\right.$ e $2 .^{\mathrm{a}}$ a partir do ápice) de plântulas de cada ecótipo de pinha (PI e CT), frente ao isolado. Para tanto, estas folhas foram destacadas, e submetidas à desinfecção superficial [imersão por 30-40 s em solução de hipoclorito de sódio em água destilada estéril $(1: 1 \mathrm{v} / \mathrm{v})$, seguida de lavagem (5-15 s) em água destilada estéril]. A superfície abaxial de 24 folhas foi, então, inoculada com 16 gotas $(50 \mu \mathrm{L})$ equidistantes de suspensão aquosa $\left(0,1 \%\right.$ de Tween 20) de conídios $\left(2 \times 10^{6} \mathrm{~mL}^{-1}\right)$ do isolado de C. gloeosporioides. Como tratamento controle, 24 folhas receberam, nas mesmas posições, 50 $\mu \mathrm{L}$ de solução aquosa $(0,1 \%$ de Tween 20$)$ estéril. Em seguida, esse material foi incubado em câmara úmida (100 \% U.R., escuro) confeccionada em bandejas com espuma de poliuretano e sacos plásticos negro-opacos, e transferido para casa-de-vegetação $\left(30 \pm 2{ }^{\circ} \mathrm{C}\right)$, por até 46 horas. Tal ensaio foi duplicado, sendo uma réplica utilizada para extração dos tecidos, e outra para análise da severidade da doença (72 horas após a inoculação), repetido em 3 ocasiões. A severidade da doença foi classificada, conforme escala de notas variando de $0-5$, onde 0 correspondeu a tecido sem lesões; 1: 5\% de tecido necrótico (TN); 2: 6-20\% TN; 3 : 21-35\% TN; 4: 36-60\% TN; 5: 61-100\% TN. Para análise final das reações, os tipos de sintomas foram categorizados em: $\mathrm{R}=$ resistentes (notas médias 0-2,9); $\mathrm{M}=$ moderadamente resistentes (nota média 3,0-3,9) e S= suscetíveis (notas médias 4,0-5,0).

Nos intervalos de 0 e 36 horas de incubação, a massa fresca (mf) de amostras de folhas dos dois tratamentos (controle e inoculado) do ensaio foi mensurada $(1,0 \mathrm{~g})$ para extração dos tecidos; estes foram seccionados e macerados (em cadinhos mergulhados em bacias de gelo) com metanol (80\%) acidificado $(0,1 \%$ de ácido tricloroacético - TCA). O extrato foi filtrado, evaporado (roto-evaporador a 40 ${ }^{\circ} \mathrm{C}, 100$ rotações $\mathrm{min}^{-1}$ ) até a secagem e solubilizado em $10 \mathrm{~mL}$ de metanol $\left(100 \mathrm{mg} \mathrm{mf} \mathrm{mL}^{-1}\right)$. Depois, foi particionado contra hexano p.a. e novamente submetido à secagem e à solubilização em metanol p.a. $(10 \mathrm{~mL})$. Nas frações polares, quantificou-se o conteúdo total de proteínas, glicídeos redutores e fenóis, conforme descrito por LowRY et al. (1951), YEMM e Willis (1954) e Bray e Thorpe (1954), respectivamente. Os resultados foram expressos como médias de 3 repetições (com 3 replicatas de cada amostra analisada).

Germinação e formação de apressórios de $C$. gloeosporioides in vivo

Paralelamente ao experimento anterior, o estudo do desenvolvimento inicial do patógeno in vivo também foi efetuado. Para tanto, 35 folhas destacadas de plântulas de cada ecótipo de pinha foram coletadas, submetidas à inoculação e incubadas nas condições acima descritas. Após 12, 18, 24, 30, 36, 42 e 46 horas de incubação, três amostras do tecido inoculado (discos de folhas com $c a$. de $0,8 \mathrm{~cm}^{2}$ ) de cada ecótipo foram coletadas e clareadas durante 30 a 90 minutos, por imersão em uma solução de etanol: clorofórmio $(3: 1 \mathrm{v} / \mathrm{v})$ contendo $0,15 \%(\mathrm{w} / \mathrm{v})$ de TCA, a $70{ }^{\circ} \mathrm{C}$. Após o clareamento, as amostras foram coradas por 60 minutos com solução de Commassie Blue R250 (0,025 \%) em metanol: ácido acético: água (5:1:4 v/v/v), lavadas com água destilada estéril, e montadas sobre lâmina de microscopia, em solução aquosa de glicerol $30 \%$. Foram considerados cem conídios em três campos de cada uma de três amostras de cinco folhas para cada intervalo de tempo, visando ao cálculo do percentual de germinação e de formação de apressórios. Esse experimento foi repetido em três ocasiões, e os resultados expressos como médias.

\section{RESULTADOS E DISCUSSÃO}

\section{Características morfoculturais}

Observou-se que o micélio aéreo do isolado de C. gloeosporioides tornou-se densamente flocoso e com coloração branco-esverdeada em BDA e Agar-Aveia, embora neste último também tenha sido observada, sob o micélio aéreo, uma massa mucilaginosa alaranjada de acérvulos e conídios. Esta também estava presente no meio Mathur, mas em maior intensidade. A cor do reverso das colônias em BDA foi verde-acizentada e, em Agar-Aveia e meio Mathur, branco-alaranjada. O melhor crescimento e a esporulação do fungo estudado ocorreram em meio 
Mathur (Tabela 1), seguido dos meios Agar-Aveia e BDA. Tais dados diferem de estudos de LenNé (1978) e López (1999), os quais relataram que o crescimento micelial de diferentes espécies de Colletotrichum e/ou isolados de C. gloeosporioides foi mais intenso em BDA do que em Agar-Aveia ou meio Mathur.

Assis et al. (2001), avaliando diferentes fontes de carbono na nutrição de isolados de $C$. gloeosporioides, verificaram que o amido proporcionou o melhor crescimento para a maioria deles, provavelmente por ser lentamente hidrolisável, gerando menor acúmulo de ácidos capazes de alterar sua taxa de desenvolvimento.

Quanto aos conídios do isolado de C. gloeosporioides estudado, sempre unicelulares, hialinos, de laterais retas e extremidades arredondadas, verificou-se que sua dimensão média foi de 14,62 +2,11 $\mu \mathrm{m} \times 5,0+0 \mu \mathrm{m}$, bem semelhante às médias dos conídios de 36 isolados de $C$. gloeosporioides $(12,0-17,0 \mu \mathrm{m} \times 5,0-6,0 \mu \mathrm{m})$ estudados por López (1999), abundantes em meio Agar-Aveia e meio Mathur, e de conídios de outros 17 isolados (10,024,0 $\mu \mathrm{m} \times 2,5-5,0 \mu \mathrm{m}$ ) obtidos por Mafacioli et al. (2006) em folhas da pupunheira (Bractris gasipaes), também abundantes em meio Agar-Aveia.

As diferenças morfoculturais de espécies de Colletotrichum são decorrentes do fator genotípico cuja expressão fenotípica, decorrente da biossíntese de enzimas e metabólitos específicos mediante estímulo de substratos particulares, permite variações culturais e de severidade ( SutTon, 1992; LóPez, 1999; MAFACiOLI et al., 2006, 2008).

Tabela 1. Caracterização morfocultural e enzimática de isolado de C. gloeosporioides obtido de lesões de antracnose em frutos de abacate, incubado em diferentes meios de cultura $\left(28+2{ }^{\circ} \mathrm{C}\right.$, escuro $)$

\begin{tabular}{lccc}
\hline Variáveis analisadas* & \multicolumn{3}{c}{ Meios de cultura } \\
\cline { 2 - 4 } & BDA & Agar-Aveia & Mathur \\
\hline Crescimento micelial $(\mathrm{mm})\left({ }^{1}\right)$ & $90,0 \pm 0,00 \mathrm{a}$ & $60,17 \pm 0,08 \mathrm{~b}$ & $80,58 \pm 0,94 \mathrm{a}$ \\
\hline Esporulação $\left(^{2}\right)$ & $(1,0 \pm 0.03) \times 10^{5} \mathrm{a}$ & $(1,66 \pm 0,00) \times 10^{5} \mathrm{a}$ & $(2,23 \pm 0,02) \times 10^{6}$ ab
\end{tabular}

Exoenzimas

$\begin{array}{lllll}\text { Degradação de substrato por } & \text { Protease } & \text { Amilase } & \text { Poligalacturonase } \mathrm{pH} 5,0 & \text { Pectatoliase } \mathrm{pH} 7,0 \quad \text { Xilanase } \\ \text { Exoenzimas }(\theta=\mathrm{mm})\left({ }^{3}\right) & & \end{array}$

$40,3 \pm 0,25$ a $\quad 50,1 \pm 0,33 \mathrm{~b} \quad 40,23 \pm 0,33 \mathrm{a} \quad 40,16 \pm 0,00 \mathrm{a} \quad 40,1 \pm 0,01 \mathrm{a}$

* Médias \pm desvio-padrão. Letras iguais na mesma linha significam que não há diferença entre as médias ao nível de 5 \% (Teste de Tuckey);

$\left({ }^{1}\right)$ Taxa crescimento micelial: Valor médio após sete dias de incubação;

$\left({ }^{2}\right)$ Taxa de esporulação: Avaliada após sete dias de incubação;

$\left({ }^{3}\right)$ Produção de exoenzimas: Avaliada após três dias de incubação (crescimento + halo).

\section{Produção de exoenzimas por C. gloeosporioides in vitro}

Verificou-se que o crescimento micelial do isolado de C. gloeosporioides estudado foi ligeiramente inferior aos diâmetros de degradação de substratos específicos presentes nos meios para ensaio das atividades enzimáticas. Porém, esses últimos foram muito evidentes, na proporção de cerca de 1:1 entre a degradação dos substratos e o crescimento (Tabela 1).

Portanto, considerando-se que um dos fatores que contribuem para se determinar o grau de agressividade de agentes fitopatológicos é a produção de exoenzimas capazes de degradar a parede e outras estruturas de células vegetais (BATEMAN e BASHAM 1976), o isolado de C. gloeosporioides proveniente de lesões de abacate revelou-se potencialmente capaz de degradar os constituintes da parede celular de folhas de pinha.
A habilidade de várias espécies de fungos em produzir enzimas é bastante variável. SILVA et al. (2006) isolaram vários microrganismos endofíticos de folhas, raízes e caule de árvores de pinha, entre eles, isolados de Colletotrichum com atividade lipolítica, porém não proteolítica, amilolítica e celulolítica. Segundo Rollof et al. (1987), a produção de lipase por fungos patogênicos está relacionada com a localização e possibilidade de expansão da infecção. No caso do isolado de C. gloeosporioides aqui estudado, constatouse a secreção não só de proteases, mas também de xilanases e pectinases, duas enzimas da parede celular vegetal, além de amilases, o que não é de se estranhar, já que permitem a hidrólise do amido até monômeros assimiláveis de glicose, sendo sua ocorrência comum em fungos. Segundo AnNis e Goodwin (1997), as diferentes isoenzimas de cada grupo de enzimas que degradam a parede celular podem ter diferentes funções, como a obtenção de nutrientes durante o crescimento saprofítico. 
Pouco é conhecido, no entanto, sobre o papel das proteases na penetração dos fungos nas plantas (GRIFFIN, 1994), embora sejam os complexos enzimáticos fúngicos relativamente mais bem estudados, com grande interesse nos processos industriais.

\section{Reações das folhas de pinha e desenvolvimento inicial do patógeno}

Quanto à manifestação dos sintomas 72 horas após a inoculação, verificou-se (dados não ilustrados) que as folhas destacadas do ecótipo CT estavam moderadamente resistentes ao isolado de $C$. gloeosporioides proveniente de abacate (média de escala de notas $=3$ ), enquanto as folhas do ecótipo PI revelaram-se suscetíveis a esse fungo (média de escala de notas $=4$ ). Vários autores já relataram que isolados de Colletotrichum de lesões de antracnose de diferentes frutíferas podem causar infecções cruzadas sob ambiente controlado (ABANG et al., 2005; SERRA et al., 2008; XIAO et al., 2004). Portanto, o fato de que $C$. gloeosporioides isolado de lesões de uma planta hospedeira diferente foi capaz de causar sintomas de suscetibilidade na pinha não representou novidade.

Com relação ao comportamento do isolado in vivo (Figura 1), verificou-se que foram necessárias 30 horas de incubação para que $80 \%$ dos conídios pudessem germinar, com ca. $50 \%$ deles formando apressórios, sobre a superfície abaxial das folhas jovens do ecótipo CT, enquanto apenas 24 horas de incubação sobre o ecótipo PI já foram suficientes para que tais índices fossem atingidos.

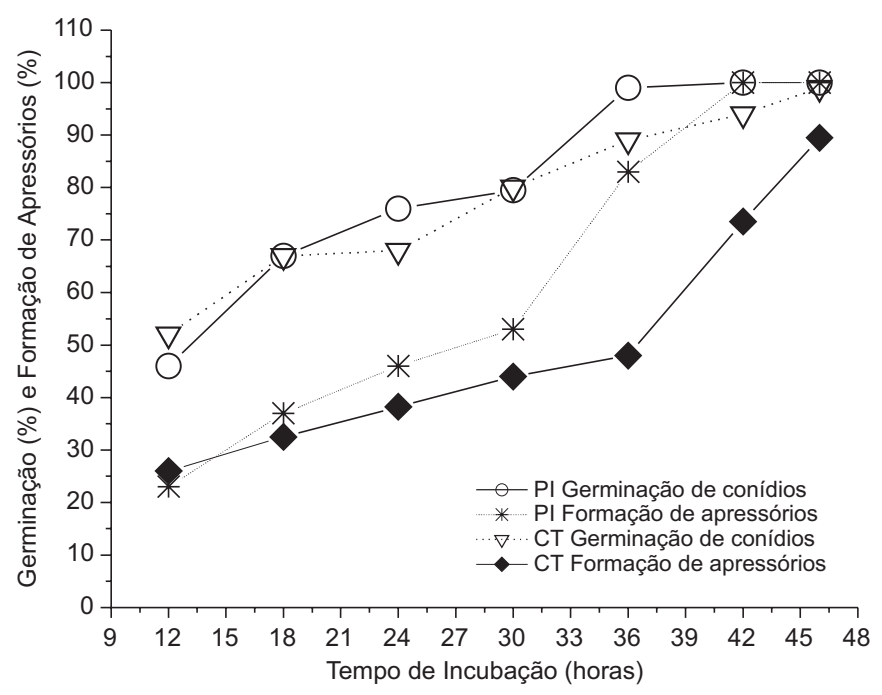

Figura 1. Germinação de conídios e formação de apressórios do isolado de C. gloeosporioides, proveniente de lesões de antracnose em frutos de abacate, após inoculação $\left(2 \times 10^{6}\right.$ conídios $\left.\mathrm{mL}^{-1}\right)$ da superfície abaxial de folhas jovens dos ecótipos de pinha "Palmeira dos Índios" (PI) e "Centenário" (CT) e incubação (100\% U.R., escuro) sob condições de casa de vegetação. Cada barra indica o valor médio de três repetições.
De acordo com López (2001), a germinação de conídios de C. gloeosporioides ocorre entre 6 e 48 horas após a inoculação, sendo esta uma característica relacionada aos eventos iniciais da interação com o hospedeiro, capaz de definir seu grau de suscetibilidade ao agente patogênico. Evidências experimentais sugerem que são necessárias aproximadamente 2 horas de contato com a superfície do tecido hospedeiro para que um grupo de genes dos conídios de C. gloeosporioides seja transcrito e traduzido como resposta às substâncias químicas das plantas, entre elas, o hormônio etileno, por exemplo. Esses genes são responsáveis pela fase que envolve a produção extracelular de enzimas hidrolíticas, além do tubo germinativo e dos deslocamentos protoplasmáticos que estão envolvidos na penetração (KolatTUKUdy et al., 2000).

Com relação às concentrações de glicídeos redutores, fenóis e proteínas totais no ecótipo CT (Figura 2) verificou-se um aumento à medida que o processo infeccioso evoluiu \{[CT 36 horas-I] $>$ [CT 36 horas-NI] $>$ [CT 0 hora] $;$; o isolado do fungo estudado só alcançou $100 \%$ de germinação e $c a$. de $70 \%$ de formação de apressórios sobre folhas desse ecótipo 42 horas após a inoculação (Figura 1).

No tocante ao ecótipo PI de pinha, o conteúdo de fenóis totais aumentou ligeiramente nas folhas inoculadas e incubadas por 36 horas, mas na concentração de glicídeos redutores não houve alteração, e o conteúdo de proteínas totais nas folhas inoculadas só aumentou com relação ao momento da inoculação $\{[$ PI 36 horas-I] $>$ [PI 0 hora $]\}$. Ainda assim, após 36 horas de incubação, os conteúdos de proteínas e de fenóis totais das folhas inoculadas do ecótipo PI foram menores do que aqueles de folhas do ecótipo CT também inoculadas $\{[C T 36$ horas-I] $>$ [PI 36 horas-I] (Figura 2).

Patógenos necrtróficos secretam enzimas e outros polipeptídeos visando à penetração e colonização dos tecidos hospedeiros (ABRAMOvitch e MARTIN, 2004), os quais matam no início da infecção, alimentando-se de moléculas de células mortas. Nessas interações, a via do jasmonato/etileno é a mais importante na defesa das plantas, acelerando a respiração e o metabolismo de carboidratos (ТноммА et al., 2001).

Estes, não só são nutrientes necessários para o crescimento, a respiração, e o armazenamento de energia para plantas e patógenos, mas, além disso, sinalizadores que podem regular a expressão gênica do metabolismo dos organismos envolvidos, como o acúmulo de hexoses regulando a fotossíntese e a defesa das plantas, ou a secreção de enzimas hidrolíticas dos fungos (BERGER et al., 2007). 

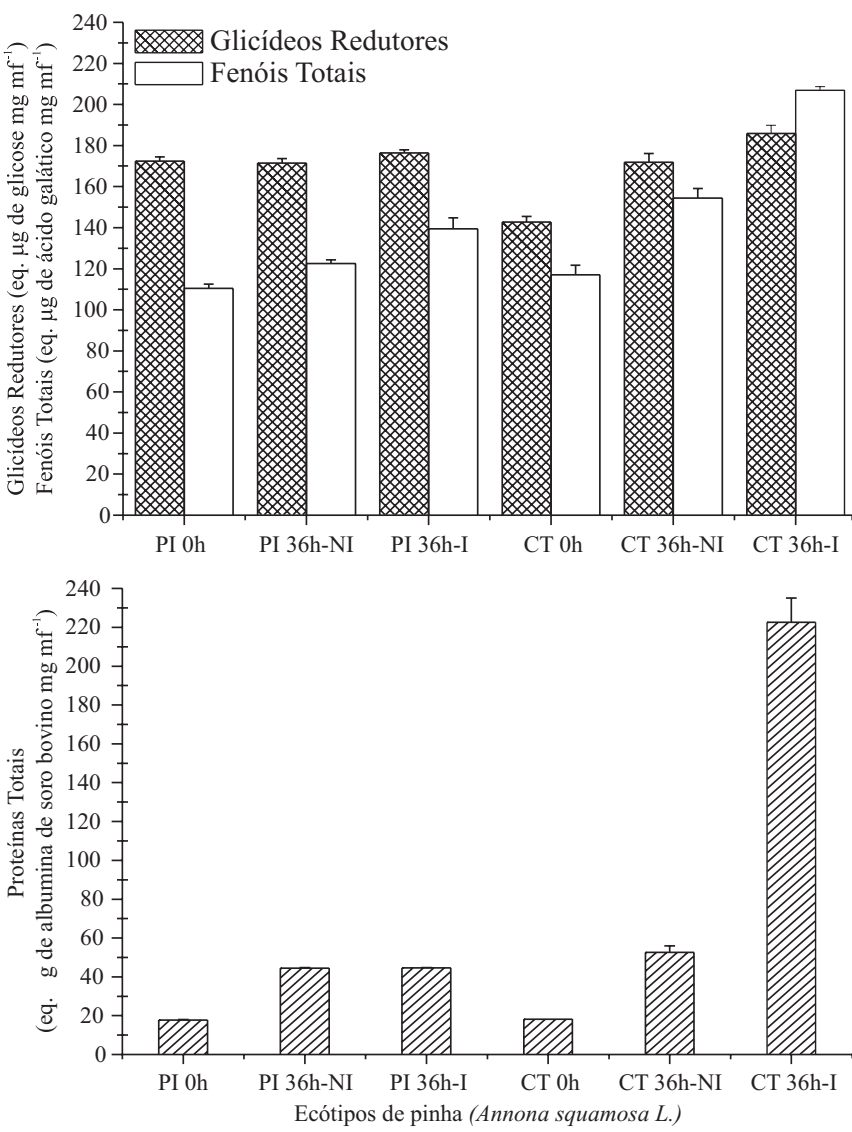

Figura 2. Respostas bioquímicas de tecidos foliares dos ecótipos de pinha "Palmeira dos Índios" (PI) e "Centenário" (CT), frente à inoculação com $C$. gloeosporioides $\left(2 \times 10^{6}\right.$ conídios $\left.\mathrm{mL}^{-1}\right)$. Fração polar de extratos foliares: tecido imediatamente extraído $(0 \mathrm{~h})$; tecido não inoculado e coletado após 36 horas de incubação (36 h-NI); tecido inoculado e coletado após 36 horas de incubação (36 h-I). Incubação das amostras (100 \% U.R., escuro) sob condições de casa de vegetação. Cada barra indica o valor médio ( \pm desvio-padrão) de três repetições.

Nesse caso, a redução da fotossíntese é um dos efeitos mais imediatos da infecção e, inicialmente, ocorre aumento na concentração de carboidratos solúveis nos tecidos; esta, em geral, decresce durante a colonização ao iniciar-se a esporulação, atingindo níveis bem menores que nos tecidos sadios. Esse aumento inicial pode estar relacionado à hidrólise de oligo e polissacarídeos, de reserva da parede celular do patógeno ou do hospedeiro (PAN et al., 1990), em função do aumento do metabolismo respiratório das células inoculadas, e/ou de compostos fenólicos glicosilados (MorkunAs et al., 2005). Invertases da parede celular dos hospedeiros, por exemplo, decompõem sacarose no apoplasto, aumentando as taxas de hexoses a serem exportadas para a célula e diminuindo sua secreção (BERGER et al., 2007).
Morkunas et al. (2007), ao estudarem a resposta de embriões de Lupinus luteus L. cv. Pólo, cultivados na presença (+) ou ausência (-) de $60 \mathrm{mM}$ de sacarose (S), frente à inoculação (i) ou não (ni) por Fusarium oxysporum Schlecht f.sp. lupini, durante 84, 96 e 108 horas de incubação, constataram acúmulo de sacarose, glicose e frutose endógenos nos embriões + Sni, e decréscimo desses glicídeos nos embriões + Si. Embora a adição de sacarose ao meio 24 horas antes da inoculação tenha atenuado significativamente a severidade da doença, sua aplicação 48 horas após a inoculação não restringiu seu desenvolvimento. Em embriões $+\mathrm{Si}$, a atividade de peroxidases, covalente e ionicamente ligadas às paredes celulares, aumentou consideravelmente até 96 horas após a inoculação, especialmente se comparada àquela de embriões +Sni. Além disso, uma diminuição na atividade da fenilalanina-amonialiase (PAL, EC 4.3.1.5, uma enzima importante para o metabolismo de fenilpropanóides), após 96 horas de incubação, foi observada em tecidos inoculados. Este resultado contrastou com aquele de um estudo anterior (Morkunas et al., 2005), que mostrara acentuado aumento na atividade da PAL e decréscimo no teor de flavonóides-glicosídicos nos embriões $+\mathrm{Si}$. No entanto, um aumento significativo no conteúdo de isoflavonas agliconas livres e na atividade de âglucosidase (EC 3.2.1.21), a qual hidrolisa isoflavonas glicosídicas, foi detectado nos embriões $+\mathrm{Si}$ em comparação com + Sni. A atividade dessa enzima foi muito maior em embriões $-\mathrm{Si}$ do que em embriões $+\mathrm{Si}$. Tais resultados sugeriram que carboidratos presentes no meio podem atuar na restrição do desenvolvimento da murcha de Fusarium tanto através da intensificação da lignificação quanto através da regulação da expressão e atividade de hidrolases que liberam agliconas livres antimicrobianas, as quais são geradas na fase de pré-penetração.

Concomitantemente às alterações no conteúdo de glicídeos solúveis, o aumento de proteínas relacionadas à patogênese (PR-proteínas) e certos compostos fenólicos tem sido associado às respostas de resistência de plantas a patógenos, e inclusive utilizado como marcador de avaliação de elicitação de resistência por agentes bióticos e abióticos em diferentes sistemas ditos compatíveis. YE et al. (1990) constataram estreita relação entre indução de resistência a Peronospora tabacina em fumo e aumento sistêmico das atividades das PRproteínas 2 (glucanases, EC 3.2.1.39) e 3 (quitinases, EC 3.2.1.14), e PAN et al. (1993) também detectaram nessas plantas, cuja resistência foi induzida previamente com esporangiósporos do mesmo patógeno, elevação do conteúdo de carboidratos solúveis. 
As PR-proteínas mencionadas foram capazes de degradar a parede celular do patógeno, gerando oligossacarídeos com ação eliciadora. Similar a muitas PR-proteínas, certas quitinases e glucanases induzidas estão localizadas no espaço intercelular dos tecidos hospedeiros, o que permite seu contato com as hifas de penetração fúngica.

Não é de surpreender, portanto, que o teor de proteínas totais nos tecidos de folhas de pinha tenha aumentado após 36 horas de incubação, especialmente no caso do ecótipo moderadamente resistente (CT), em que a inoculação acentuou ainda mais essa concentração. Tais moléculas selam o processo de interação plantamicrorganismo (PARKer e COLEMAN, 1997; Bogdanove, 2002; XiA, 2004) desde a recepção de estímulos externos até sua conversão em sinais para ativação de genes de resistência.

Portanto, mais estudos bioquímicos sobre os eventos iniciais da interação pinha- $C$. gloeosporioides devem ser realizados visando também ao desenvolvimento de variedades mais resistentes.

\section{CONCLUSÕES}

1. Para o controle da antracnose de pinha, faz-se importante o conhecimento quanto à sua resposta frente às variantes de $C$. gloeosporioides que infectam diferentes hospedeiros. $\mathrm{O}$ isolado de lesões de abacate in vitro secreta enzimas capazes de favorecer sua penetração em células vegetais em geral (amilase, xilanase, pectinases e proteases). Além disso, após 24 horas de inoculação in vivo, este atinge ca. de $80 \%$ de germinação e $50 \%$ de formação de apressórios sobre folhas do ecótipo PI de pinha, que manifesta sintomas de suscetibilidade apenas 48 horas depois disso.

2. A biossíntese de proteínas e a síntese/ transformação dos compostos fenólicos presentes no grupo $\mathrm{CT}$, contudo, é rápida o suficiente para retardar a germinação superficial e formação de apressórios desse fungo, que só atinge a marca alcançada nos tecidos de PI após 30 horas da inoculação, e mesmo 42 horas depois disso os sintomas resultaram em moderada resistência em CT.

3. O conteúdo semelhante de glicídeos redutores de folhas inoculadas e não inoculadas do ecótipo PI indica que ou o processo de síntese/ expressão de glicosidases intracelulares, relacionadas à liberação de agliconas tóxicas, não é rapidamente acionado frente ao isolado testado, e/ou este hidrolisa oligo e polissacarídeos do apoplasto e parede celular vegetal.
4. Moléculas precursoras dos mecanismos ativos de defesa nos tecidos foliares de pinha são necessárias ao combate do patógeno testado, comprovando que as práticas de controle devem também considerar o inóculo residual presente em tecidos atacados por antracnose de plantas associadas e invasoras.

\section{AGRADECIMENTOS}

À FAPEAL, pelo suporte financeiro aos experimentos, e ao $\mathrm{CNPq}$, pela bolsa de Iniciação Científica.

\section{REFERÊNCIAS}

ABANG, M.M.; FAGBOLA, O.; SMALLA, K.; WINTER, S. Two genetically distinct populations of Colletotrichum gloeosporioides Penz. causing anthracnose disease of yam (Discorea spp.). Journal of Phytopathology, v.153, p.137-142, 2005.

ABRAMOVITCH, R.B.; MARTIN, G.B. Strategies used by bacterial pathogens to suppress plant defenses. Current Opinion on Plant Biology, v.7, p.356-364, 2004.

ANNIS, S.L.; GOODWIN, P.H. Recent advances in the molecular genetics of plant cell wall degrading enzymes produced by plant pathogenic fungi. European Journal of Plant Pathology, v.103, p.1-14, 1997.

ARAÚJO FILHO, G.C.; ANDRADE, O.M.S.; CASTRO, F.A.; SÁ, F.T. Instruções Técnicas para o cultivo da Ateira. Embrapa Agroindústria Tropical, v.1, p.1-9, 1998.

ASSIS, T.C.; MENEZES, M.; ANDRADE, D.E.G.T.; COELHO, R.S.B.; OLIVEIRA, S.M.A. Estudo comparativo de isolados de C. gloeosporioides quanto ao efeito da nutrição de carboidratos no crescimento, esporulação e patogenicidade em frutos de três variedades de mangueira. Summa Phytopathologica, v.21, p.208-212, 2001.

BATEMAN, D.F.; BASHAM, H.G. Degradation of plant-cell walls and membranes by microbial enzymes. Physiological and Molecular Plant Pathology, v.4, p.316-355. 1976.

BERGER, S.;SINHA, A.K.; ROITSCH, T. Plant physiology meets phytopathology: plant primary metabolism and plantpathogen interactions. Journal of Experimental Botany, v.58, p.4019-4026, 2007.

BOGDANOVE, A.J. Protein-protein interactions in pathogen recognition by plants. Plant Molecular Biology, v.50, p.981989, 2002.

BRAY, H.G.; THORPE, W.V. Analysis of phenols compounds of interest in metabolism. In: GLICK, D. (Ed.). Methods of Biochemical Analysis. New York: Interscience, 1954. v.1, p.27-52.

BRITO, A.O.; NORONHA, E.P.; FRANÇA, L.M.; BRITO, L.M.O.; PRADO, M.S-A. Análise da composição fitoquímica do extrato etanólico das folhas da Annona squamosa (ATA). Revista Brasileira de Farmácia, v.89, p.180-184, 2008. 
DANN, E. K.; MEUWLY, P.; MÉTRAUX, J.P.; DEVERAL, B.J. The effect of pathogen inoculation or chemical treatment on activities of chitinase and b-1,3-glucanase and accumulation of salicylic acid in leaves of green bean Phaseolus vulgaris L. Physiological and Molecular Plant Pathology, v.49, p.307-319, 1996.

DEAN, R.A.; KUC', J. Rapid lignification in response to wounding and infection as a mechanism for induced systemic protection in cucumber. Physiological and Molecular Plant Pathology, v.31, p.69-81, 1987.

ECHEVERRI, F.; TORRES, F.; QUINONES, W.; CARDONA, G.; ARCHBOLD, R.; ROLDAN, J.; BRITO, I.; LUIS, J.G.; LAHLOU, E.H. Danielone, a phytoalexin from papaya fruit. Phytochemistry, Amsterdan, v.44, p.255-256, 1997.

ESQUERRÉ-TUGAYÉ, M.T.; MASAU, D.; BARTHE, J.P.; LAFITTE C.; TOUZÉ, A. Mechanisms of resistance to Colletotrichum species. In: BAILEY, J.A.; JEGER, M.J. (Eds.). Colletotrichum: Biology, Pathology and Control. England: CAB International, 1992. p.121-133.

FAWE, ABOUZAID, M.; MENZIES, J.G.; BELANGER, R.R. Silicon-mediated accumulation of flavonoid phytoalexins in cucumber. Phytopathology, v.88, p.396-401, 1998.

FERREIRA, L.F.R.; PEREIRA, D.S.T.; TEIXEIRA, A.P.S.; LOPEZ, A.M.Q. Eventos iniciais da interação Annona squamosa Colletotrichum gloeosporioides. In: CONGRESSO BRASILEIRO DE FITOPATOLOGIA, 35.,2002, Recife. Resumos... Recife: Sociedade Brasileira de Fitopatologia, 2002. v.7, p.S109.

GRIFFIN, D.H. Fungal Physiology. New York: Willey-Liss, 1994.

HANKIN, L.; ANAGNOSTAKIS, S.L. The use of solid media for detection of enzime production by fungi. Mycologia, v.67, p.597-607, 1975.

HARRISON, S.J.; CURTIS, M.D.; MCINTYRE, C.L.; MACLEAN, D.; MANNERS, J.M. Differential expression of peroxidase isogenes during the early stages of infection of the tropical forage legume Stylosanthes humilis by Colletotrichum gloeosporioides. Molecular Plant-Microbe Interactions, v.8, p.398-406, 1995.

KOLATTUKUDY, P. E., KIM, D. Y.-K.; LI, LIU, Z.-M.; ROGERS, L. Early molecular communication between Colletotrichum gloeosporioides and its host. In: DICKMAN, M.; FREEMAN, S.; PRUSKY, D. (Ed.). Host specificity, pathology and host pathogen interaction of Colletotrichum. Minn: The American Phytopathological Society, 2000. p.78-98.

LATUNDE-DADA, O.; LUCAS, J.A. The plant defence activator acibenzolar-S-methyl primes cowpea [V. unguiculata (L.) Walp.] seedlings for rapid induction of resistance. Physiological and Molecular Plant Pathology, v.58, p.199208, 2001.

LATUNDE-DADA, O.; LUCAS, J.A. Localized hemibiotrophy in Colletotrichum: cytological and molecular taxonomic similarities among C. destructivum, C. linicola and C. truncatum. Plant Pathology, v.56, p.437-447, 2007.
LENNÉ, J. M. Studies on the biology and taxonomy of Colletotrichum species. 1978. v.1, 187p. Ph.D. Thesis (Agriculture). University of Melbourne, Melbourne, Australia.

LÓPEZ, A.M.Q. Controle alternativo da antracnose causada por Colletotrichum graminicola (Ces.) Wils. em sorgo Sorgum bicolor L. (Moench). 1991. 230p. Dissertação (Mestrado em Microbiologia Aplicada) - Instituto de Biociências, Universidade Estadual Paulista "Júlio de Mesquita Filho", Rio Claro, São Paulo.

LÓPEZ, A.M.Q. The interaction between antracnose, Colletotrichum gloeosporioides Penz., and cashew, Anacardium occidentale (L.). 1999. 276p. PhD thesis (Molecular Plant Pathology) - Long Ashton Research Station, University of Bristol, Bristol, UK.

LÓPEZ, A.M.Q. Taxonomia, patogênese e controle de espécies do gênero Colletotrichum. Revisão Anual de Patologia de Plantas, v.9, p.291-337, 2001.

LÓPEZ, A. M. Q. Doenças de plantas cultivadas: Anonáceas e Urucuzeiro. In: BERGAMIM FILHO, A.; AMORIM, L.; KIMATI, H. (Org.). Manual de Fitopatologia II: Doenças das grandes culturas. 4.ed. Piracicaba: Agroceres, 2005. v.2, p.73-78.

LÓPEZ, A.M.Q; LUCAS, J.A. Effects of plant defense activators on anthracnose disease of cashew. European Journal of Plant Pathology, v.108, p.409-420, 2002.

LOWRY, O.H., ROSEBROUGH, N.J., FARR, A.L., RANDALL, R.J. Protein measurement with the folin phenol reagent. Journal of Biological Chemistry, v.193, p.265-275, 1951.

MAFACIOLI, R.; TESSMANN, D.J.; SANTOS, A.F.; VIDA, J.B. Caracterização morfo-fisiológica e patogenicidade de Colletotrichum gloeosporioides da pupunheira. Summa Phytopatholologica, v.32, p.113-117, 2006.

MAFACIOLI, R.; TESSMANN, D.J.; SANTOS, A.F.; VIDA, J.B. Variabilidade patogênica e efeito de carboidratos no crescimento micelial, esporulação e agressividade de Colletotrichum gloeosporioides da pupunheira. Summa Phytopatholologica, v.34, p.18-21, 2008.

MATHUR, R.S.; BARNETT, H.L.; LILLY, V.G. Sporulation of Colletotrichum lindemuthianum in culture. Phytopathology, v.40, p.104-114, 1950.

MATTOS, L. Cultura da pinha gera emprego e renda. Jornal A Tarde. Disponível em: http:/ / www.seagri.ba.gov.br/ noticias.asp?qact=view\&notid $=11054$. Acesso em 31 de julho de 2007.

MAZAU, D.;ESQUERRÉ-TUGAYÉ, M.T. Hydroxyproline-rich glycoprotein accumulation in the cell walls of plants infected by various pathogens. Physiological and Molecular Plant Pathology, v.29, p.147-157, 1986.

MORIN, L.; DERBY, J-A.L.; KOKKO, E.G. Infection process of C. gloeosporioides f.sp. malvae on Malvaceae weeds. Mycology Research, v.100, p.165-172, 1996. 
MORKUNAS, I.; MARCZAK, L.; STACHOWIAK, L.; STOBIECKI, M. Sucrose-induced lupine defense against Fusarium oxysporum: Sucrose-stimulated accumulation of isoflavonoids as a defense response of lupine to Fusarium oxysporum. Plant Physiology and Biochemistry, v.43, p.363373, 2005.

MORKUNAS, I.; KOZ£OWSKA, M.; RATAJCZAK, L.; MARCZAK, L. Role of sucrose in the development of Fusarium wilt in lupine embryo axes. Physiological and Molecular Plant Pathology, v.70, p.25-37, 2007.

MOULD, M.J.R.; BOLAND, G.J.; ROBB, J. Ultrastructure of Colletotrichum trifolii-Medicago sativa pathosystem. I-Prepenetration events. Physiological and Molecular Plant Pathology, v.38, p.179-194, 1991a.

MOULD, M.J.R.; BOLAND, G.J.; ROBB, J. Ultrastructure of Colletotrichum trifolii - Medicago sativa pathosystem. II-Postpenetration events. Physiological and Molecular Plant Pathology, v.38, p.195-210, 1991b.

PAN, S. Q.; YE, X.S.; KUC', J. Soluble carbohydrate levels in tobacco systemically protected against blue mold by stem injection with $P$. tabacina or leaf inoculation with Tobacco Mosaic Virus. Phytopathology, v.83, p.906-909, 1993.

PARKER, J.E.; COLEMAN, M.J. Molecular intimacy between proteins specifying plant-pathogen recognition. Trends in Biochemical Science, v.22, p.291-296, 1997.

PELINSON, G.J.B.; BOLIANI, A.C.; TARSITANO, M.A.A.; CORREA, L.S. Análise do custo de produção e lucratividade na cultura de pinha (Annona squamosa L.) na região de Jales-SP, ano agrícola 2001-2002. Revista Brasileira de Fruticultura, v.27, p.226-229, 2005.

PONTE, J.J. Clínica de doenças de plantas. Edições UFC, Fortaleza: EUFC, 1996.

Rollof, S.; Hedstrom, S.A.; Nilsson-Ehle, P. Purification and characterization of a lipase from Staphylococcus aureus. Biochimica et Biophysica Acta, v.921, p.363-369, 1987.

SERRA, I.M.R.S.; COELHO, R.S.B.; MENEZES, M. Caracterização fisiológica, patogênica e análise isoenzimática de isolados monospóricos e multispóricos de Colletotrichum gloeosporioides. Summa Phytopathologica, v.34, p.13-120, 2008.

SILVA, R.L.O.; LUZ, J. S.; SILVEIRA, E. B.; CAVALCANTE, U. M. T. Fungos endofíticos em Annona spp.: isolamento, caracterização enzimática e promoção do crescimento em mudas de pinha (Annona squamosa L.). Acta Botanica Brasilica, v.20, p.649-655, 2006.

SOMMER-KNUDSEN, J.; BACIC, A.; CLARKE, A. Hydroxyproline-rich plant glycoproteins. Phytochemistry, v.47, p.483-497, 1998.

SUTTON, B.C. The genus Glomerella and its anamorph Colletotrichum. In: BAILEY, J.A.; JEGER, M.J. (Eds.). Colletotrichum: Biology, Pathology and Control. England: CAB International, 1992. p.1-26.
THOMMA, B.P.H.J.; PENNINCKX, I.A.; BROEKAERT, W.F.; CAMMUE, B.P. The complexity of disease signaling in Arabidopsis. Current Opinion in Immunology, v.13, p.6368, 2001.

TU, J.C. An improved Mathur's medium for growth, sporulation, and germination of spore of Colletotrichum lindemutianum. Microbios, v.44, p.87-93, 1985.

XIA, Y. Related Proteases in pathogenesis and plant defense. Cell Microbiology, v.6, p.905-913, 2004.

XIAO, C.L.; MACKENZIE, S.J.; LEGARD, D.E. Genetic and pathogenic analysis of Colletotrichum gloeosporioides isolates from strawberry and non-cultivated hosts. Phytopathology, v.94, p.446-453, 2004.

XUE, L.; CHAREST, P.M.; JABAJIHARE, S.H. Systemic induction of peroxidases, 1,3-b-glucanases, chitinases and resistance in bean plants by binucleate Rhizoctonia species. Phytopathology, v.88, p.359-365, 1998.

YE, X.S.; PAN, Q.; KUC', J. Association of pathogenesis-related proteins and activities of peroxidase, â-1,3-glucanase and chitinase with systemic induced resistance to blue mould of tobacco but not to systemic tobacco mosaic vírus. Physiological and Molecular Plant Pathology, v.36, p.523-531, 1990.

YEMM, E.W.; WILLIS, A.J. The estimation of carbohydrates in plant extracts by anthrone. Biochemistry Journal, v.57, p.508$514,1954$. 